\title{
Enoxacin as one day oral treatment of men with anal or pharyngeal gonorrhoea
}

\author{
M BAKHTIAR, * P L SAMARASINGHE $\dagger$ \\ From the Departments of *Medical Microbiology and $\dagger$ Genitourinary Medicine, Westminster Hospital, London
}

SUMMARY The efficacy of two regimens of oral enoxacin $(400 \mathrm{mg}$ as a single dose or two $200 \mathrm{mg}$ doses 12 hours apart) to treat anal and pharyngeal gonorrhoea was compared. Fifty men with confirmed gonorrhoea (40 with anal, six with pharyngeal, and four with both) were treated and assessed three to five and seven to 14 days after treatment. Of 44 evaluable patients who attended the first follow up, including those who were infected with penicillinase producing Neisseria gonorrhoeae (PPNG), all were cured. No haematological or biochemical abnormality associated with enoxacin was observed. Nine patients reported minor adverse effects during the trial period, only one of which was considered probably related to the treatment. Both regimens of $400 \mathrm{mg}$ enoxacin were effective in treating anal and pharyngeal gonorrhoea.

The recent rise in resistance of clinical isolates of Neisseria gonorrhoeae to antibiotics has led clinicians to search for alternative antibacterial agents to treat this common venereal infection. New quinolone derivatives with their high in vitro activity and oral administration are potentially useful, and successful treatment of urethral gonorrhoea has been reported using these agents. ${ }^{12}$

Enoxacin, a fluorinated derivative of pipemidic acid, is a new oral quinolone preparation that has been shown to have in vitro activity against Staphylococcus aureus and a wide range of aerobic Gram negative organisms including $N$ gonorrhoeae. ${ }^{34}$

Enoxacin has been reported to have a larger volume of distribution and greater tissue concentrations than other newly developed quinolones such as ciprofloxacin and norfloxacin, ${ }^{56}$ and has been successfully used to treat urethral gonorrhoea as a single $600 \mathrm{mg}$ oral dose. ' In this study we compared the efficacy of two dosage regimens of enoxacin with a total dose of $400 \mathrm{mg}$ in treating pharyngeal and rectal gonorrhoea.

\section{Patients, materials, and methods}

We studied 50 men attending the genitourinary medicine outpatient department at the Westminster Hospital to compare two dosage regimens of enoxacin, a single $400 \mathrm{mg}$ dose or two $200 \mathrm{mg}$ doses 12

Address for reprints: Dr $M$ Bakhtiar, Department of Medical Microbiology, Westminster Hospital, 17 Horseferry Road, London SW1P 2AR

Accepted for publication 12 April 1988 hours apart. The study was approved by the hospital Ethics Committee. Patients aged between 18 and 65 with anal or pharyngeal gonococcal infections, or both, were eligible for inclusion. Patients with any renal or hepatic impairment, disseminated gonorrhoea or syphilis, or a known allergy to quinolone derivatives, or who had previously been treated with enoxacin were excluded from the study. Of the 50 men (mean age of 29.9 (range 20-54) years), 48 were homosexual, one was bisexual, and one heterosexual. All gave fully informed consent to taking part in this study. Table 1 gives the characteristics of the patients, which were comparable for the two treatment groups. Clinical diagnosis was based on the presence of rectal discharge, anorectal pain or itching, and sore throat; these symptoms were assessed as absent, mild, moderate, or severe. Initial diagnosis was further suggested in some patients by evidence of intracellular Gram negative diplococci on Gram stained anal or pharyngeal smears, and was confirmed by the isolation of $N$ gonorrhoeae on selective media. Table 2 gives

Table 1 Characteristics of 50 men with gonorrhoea treated with enoxacin $400 \mathrm{mg}$ as one dose or in two equal doses 12 hours apart

\begin{tabular}{lll}
\hline & $\begin{array}{l}\text { Single dose } \\
(n=25)\end{array}$ & $\begin{array}{l}\text { Two doses } \\
(n=25)\end{array}$ \\
\hline Mean (range) age (years) & $27(19-54)$ & $32(20-46)$ \\
No HIV antibody positive & 5 & 6 \\
No homosexual & 25 & 23 \\
No heterosexual & 0 & 1 \\
No bisexual & 0 & 1 \\
\hline
\end{tabular}


Table 2 Diagnosis and symptoms of 50 men with gonorrhoea treated with enoxacin $400 \mathrm{mg}$ as a single dose or two equal doses 12 hours apart

\begin{tabular}{|c|c|c|c|c|c|}
\hline \multirow[b]{2}{*}{ Site of infection } & \multirow[b]{2}{*}{$n$} & \multicolumn{2}{|c|}{ Symptoms before single dose } & \multicolumn{2}{|c|}{ Symptoms before two doses } \\
\hline & & Present & Absent & Present & Absent \\
\hline $\begin{array}{l}\text { Anus } \\
\text { Pharynx } \\
\text { Anus plus pharynx }\end{array}$ & $\begin{array}{r}40 \\
6 \\
4\end{array}$ & $\begin{array}{r}11 \\
2 \\
1\end{array}$ & $\begin{array}{l}8 \\
1 \\
2\end{array}$ & $\begin{array}{r}13 \\
1 \\
1\end{array}$ & $\begin{array}{l}8 \\
2 \\
0\end{array}$ \\
\hline Total & 50 & 14 & 11 & 15 & 10 \\
\hline
\end{tabular}

diagnoses and symptoms; 40 patients had anal gonorrhoea (16 of whom were symptomless), six had pharyngeal gonorrhoea (three of whom were symptomless), and four had both anal and pharyngeal gonorrhoea, (two of whom were symptomless).

In a double blind, randomised, comparative trial we treated 25 men with $400 \mathrm{mg}$ enoxacin as a single dose, and 25 with two doses of $200 \mathrm{mg}$ enoxacin 12 hours apart. Blinding was achieved using identical placebo capsules, one given with each $200 \mathrm{mg}$ dose of enoxacin to the men receiving two doses and two given 12 hours after the $\mathbf{4 0 0} \mathbf{m g}$ dose to the men receiving one dose. Patients were asked to refrain from sexual activity during the whole study period. Follow up examinations with clinical evaluation and direct microscopy, were made at three to five and seven to 10 days after treatment. Cultures of material from the anus or pharynx, or both, were also carried out at each visit. Patients were questioned regarding their sexual activity since treatment. Blood was taken before and after treatment for haematological and biochemical investigations.

Using an agar doubling dilution method, ${ }^{23}$ we measured the minimum inhibitory concentrations (MICs) of enoxacin, ampicillin, benzylpenicillin, piperacillin, and cefuroxime against each strain of $N$ gonorrhoeae. Isolates were also tested for $\beta$ lactamase production.

\section{Results}

Of the 50 men, 44 were clinically symptom free and bacteriologically cured when examined three to five days after treatment (table 3). One had had sexual contact with his original partner after treatment, and a second isolate of $\mathbf{N g o n o r r h o e a e}$ was shown to have the same sensitivity pattern as the original strain. Five men were lost to follow up at that stage. Thus both regimens were completely successful in evaluable patients. The MICs of enoxacin against all the gonococci isolated in this study, including three $\beta$ lactamase producers, were very low $\left(\mathrm{MIC}_{90}=0.12 \mathrm{mg} / \mathrm{l}\right.$, range $0.025-0.25 \mathrm{mg}$ ). The MICs of other antibiotics were considerably more variable (ampicillin $\mathbf{M I C}_{90}=$ $1.0 \mathrm{mg} / \mathrm{l}$, range $0.06->16 \mathrm{mg} / \mathrm{l}$; benzylpenicillin
Table 3 Bacteriological results (at two follow up visits) of treatment with enoxacin $400 \mathrm{mg}$ as single dose or in two equal doses 12 hours apart

\begin{tabular}{|c|c|c|c|c|}
\hline & \multicolumn{2}{|c|}{$\begin{array}{l}\text { Follow up at } \\
3-5 \text { days }\end{array}$} & \multicolumn{2}{|c|}{$\begin{array}{l}\text { Follow up at } \\
7-10 \text { days }\end{array}$} \\
\hline & $\begin{array}{l}\text { Single } \\
\text { dose }\end{array}$ & $\begin{array}{l}\text { Two } \\
\text { doses }\end{array}$ & $\begin{array}{l}\text { Single } \\
\text { dose }\end{array}$ & $\begin{array}{l}\text { Two } \\
\text { doses }\end{array}$ \\
\hline $\begin{array}{l}\text { Cured } \\
\text { Treatment failed } \\
\text { Lost to follow up } \\
\text { Withdrawn from protocol }\end{array}$ & $\begin{array}{r}22 \\
0 \\
2 \\
1\end{array}$ & $\begin{array}{r}22 \\
0 \\
3 \\
0\end{array}$ & $\begin{array}{r}15 \\
0 \\
10 \\
0\end{array}$ & $\begin{array}{r}18 \\
0 \\
7 \\
0\end{array}$ \\
\hline Total & 25 & 25 & 25 & 25 \\
\hline
\end{tabular}

$\mathrm{MIC}_{90}=2.0 \mathrm{mg} / \mathrm{l}$, range $0.03->16 \mathrm{mg} / \mathrm{l}$; cefuroxime $\mathrm{MIC}_{90}=1.0 \mathrm{mg} / 1$, range $0.06-2.0 \mathrm{mg} / 1 ;$ and piperacillin $\mathrm{MIC}_{90}=1.0 \mathrm{mg} / \mathrm{l}$, range $0.03->16 \mathrm{mg} / \mathrm{l}$ ).

No major clinical adverse reactions occurred in any of the patients (including 11 with antibody to HIV), and haematological and biochemical markers were not affected. Nine patients, five who received a single dose and four who received two doses, complained of mild adverse events ranging from a slight headache to light diarrhoea, but these events were not always related to the treatment. A second follow up appointment seven to 10 days after treatment showed a continuation of cure in all the men examined, though 17 men failed to attend this appointment.

\section{Discussion}

The occurrence of resistance to antibiotics has forced clinicians to use antibiotics other than those previously used to treat rectal or pharyngeal gonorrhoea. $\beta$ lactamase resistant parenteral cephalosporins can be useful against resistant strains, although mechanisms of resistance other than the production of $\beta$ lactamase have been described in the United States of America. ${ }^{8}$ Furthermore, Hook and Holmes reported in 1985 that gonococci isolated from homosexual men with rectal gonorrhoea carry " $m$ tr" genes that confer a degree of resistance to several antibiotics."

The quinolone derivatives have previously been successfully used orally to treat gonorrhoea. ${ }^{17}$ In our 
study all patients were cured of anorectal and pharyngeal gonorrhoea using $400 \mathrm{mg}$ enoxacin. The single patient withdrawn from the study gave evidence of reinfection, rather than lack of response to treatment. The gonococci isolated after reinfection from this patient had the same sensitivity to enoxacin as the original isolate, in contrast to the finding of Wagenwoort et al in 1986, who reported development of resistance to enoxacin in gonococci during treatment. ${ }^{10}$ No serious side effects attributed to enoxacin were observed in this study.

In the light of these results we think that $400 \mathrm{mg}$ enoxacin given orally as a single or divided dose is an effective treatment for rectal and pharyngeal gonorrhoea.

\section{References}

1 Shahmanesh M, Shukla SR, Phillips I, Westwood A, Thin RN. Ciprofloxacin for treating urethral gonorrhoea in men. Genitourin Med 1986;62:86-7.

2 Notowicz A, Stolz E, van Klingeren B. A double-blind study comparing two dosages of enoxacin for the treatment of uncomplicated urogenital gonorrhoea. J Antimicrob Chemother 1984;14 suppl C:91-4.

3 Selwyn S, Bakhtiar M. Comparative in-vitro studies on a new azaquinolone, enoxacin. Drugs under Experimental and Clinical Research 1984;10:669-76.

4 Wise R, Andrews JM, Danks G. In-vitro activity of enoxacin (CI919), a new quinolone derivative, compared with that of other antimicrobial agents. J Antimicrob Chemother 1984;13:237-44.

5 Davis BI, Maesen FPV, Teenys JP. Serum and sputum concentrations of enoxacin after single oral dosing in a chemical and bacteriological study. J Antimicrob Chemother 1984;14:83-9.

6 Honeybourne D, Wise R, Andrews JM. Ciprofloxacin penetration into lungs. Lancet $1987 ; \mathrm{i}: 1040$.

7 Siboulet A, Catalan F, Bohbot J-M. Enoxacin in the treatment of sexually transmitted diseases. J Antimicrob Chemother 1988;21 suppl B:119-24.

8 Faruki H, Sparling PF. Genetics of resistance in a non-betalactamase producing gonococcus with relatively high level of penicillin resistance. Antimicrob Agents Chemother 1986;30: 856-60.

9 Hook EW, Holmes KK. Gonococcal infections. Ann Intern Med 1985;102:229-43.

10 Wagenvoort JHT, van der Willigen AH, van Vliet HJA, Michel MF, van Klingeren B. Resistance of Neisseria gonorrhoeae to enoxacin. J Antimicrob Chemother 1986;18:429. 